\title{
Mass distributions and morphological and chemical characterization of urban aerosols in the continental Balkan area (Belgrade)
}

\author{
D. Đorđević ${ }^{1}$ - J. Buha ${ }^{2,3,4}$ - A. M. Stortini ${ }^{5}$ - A. Mihajlidi-Zelić ${ }^{1}$ - D. Relić $^{6}$. \\ C. Barbante B, A. Gambaro $^{7,8}$
}

Received: 30 April 2015 / Accepted: 17 August 2015 /Published online: 8 September 2015

(C) Springer-Verlag Berlin Heidelberg 2015

\begin{abstract}
This work presents characteristics of atmospheric aerosols of urban central Balkans area, using a sizesegregated aerosol sampling method, calculation of mass distributions, SEM/EDX characterization, and ICP/MS analysis. Three types of mass distributions were observed: distribution with a pronounced domination of coarse mode, bimodal distribution, and distribution with minimum at $1 \mu \mathrm{m}$ describing the urban aerosol. SEM/EDX analyses have shown morphological difference and variation in the content of elements in samples. EDX spectra demonstrate that particles generally contain the following elements: $\mathrm{Al}, \mathrm{Ca}, \mathrm{K}, \mathrm{Fe}, \mathrm{Mg}, \mathrm{Ni}, \mathrm{K}$, $\mathrm{Si}$, S. Additionally, the presence of $\mathrm{As}, \mathrm{Br}, \mathrm{Sn}$, and $\mathrm{Zn}$ found in air masses from southeast segment points out the anthropogenic activities most probably from mining activities in southeastern part of Serbia. The ratio $\mathrm{Al} / \mathrm{Si}$ equivalent to the ratio of desert dust was associated with air masses coming from southeastern and southwestern segments, pointing to influences from North Africa and Middle East desert areas whereas the $\mathrm{Al} / \mathrm{Si}$ ratio in other samples is significantly lower. In several samples, we found high values of aluminum in the nucleation
\end{abstract}

Responsible editor: Constantini Samara

D. Đorđević

dragadj@chem.bg.ac.rs

1 University of Belgrade, Centre of Chemistry - ICTM, Studentski trg 14-16, 11000 Belgrade, Serbia

2 Analytical Chemistry Laboratory, Empa - Swiss Federal Laboratories for Material Science and Technology, Dübendorf 8600, Switzerland

3 Institute of Environmental Engineering, ETH Zurich, Zurich 8093, Switzerland

4 Technology and Society Laboratory, Empa - Swiss Federal Laboratories for Material Science and Technology, St. Gallen 9014, Switzerland mode. Samples with low share of crustal elements in the coarse mode are collected when Mediterranean air masses prevailed, while high share in the coarse mode was associated with continental air masses that could be one of the approaches for identification of the aerosol origin.

Keywords Continental urban aerosols · Size distributions · Morphologies

\section{Introduction}

The properties of atmospheric aerosols show spatial and temporal variability. Depending on their elemental composition, the scattering, and absorption of light by airborne particles may vary. Atmospheric aerosols containing sulfates are regarded as primary particles responsible for the net cooling effect by scattering of solar radiation and by acting as cloud condensation nuclei (CCN) (Mogo et al. 2005). The negative radiative forcing further leads to the cooling of Earth's surface.

5 Department of Molecular Sciences and Nanosystems, University Ca' Foscari of Venice, Dorsoduro 2137, 30123 Venice, Italy

6 Faculty of Chemistry, University of Belgrade, Studentski trg 12-16, 11000 Belgrade, Serbia

7 Department of Environmental Sciences, Informatics and Statistics, University Ca' Foscari of Venice, Dorsoduro 2137, 30123 Venice, Italy

8 Institute for the Dynamics of Environmental Processes - National Research Council (CNR-IDPA), Dorsoduro 2137, 30123 Venice, Italy 
On the other hand, soot or black carbon is well known absorber of solar radiation causing a warming effect (Mogo et al. 2005).

The diameter of the atmospheric particles can span over four orders of magnitude and in this wide-size range; for example, the mass of a $10-\mu \mathrm{m}$ particle is equivalent to the mass of one billion 10-nm particles (Seinfeld and Pandis 1998; Heintzenberg et al. 2011). The distribution of particle mass with respect to particle size, $n_{M}\left(D_{p}\right)$ (Eq. (1)), is

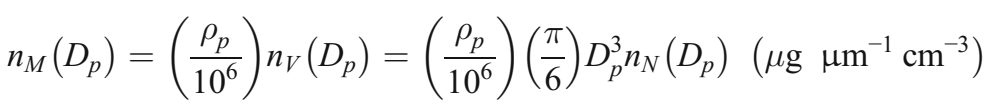

where $\rho_{p}$ is the particle density $\left(\mathrm{g} \mathrm{cm}^{-3}\right), n_{V}\left(D_{p}\right)$ is the particle volume distribution with respect to particle size $\left(\mu \mathrm{m}^{2} \mathrm{~cm}^{-3}\right)$, $D_{p}$ is the particle diameter $(\mu \mathrm{m})$, and the factor $10^{6}$ converts the units of density $\rho_{p}$ from $\mathrm{g} \mathrm{cm}^{-3}$ to $\mu \mathrm{g} \mu \mathrm{m}^{-3}$ to maintain the

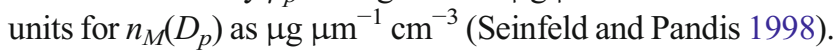

The aerosol-size distributions of urban areas usually have two distinct modes, one in submicron regime and the other in the coarse particle regime. Mass distributions of urban aerosols are characterized by a minimum between 1 and $3 \mu \mathrm{m}$. For the size distribution of marine aerosol, it is typical that the coarse mode comprises $95 \%$ of the total mass and $5-10 \%$ of the particle number. The characteristics of rural continental aerosol are domination of the coarse mode centered at about $7 \mu \mathrm{m}$ in mass distribution. The main components of remote continental aerosol are primary particles and secondary oxidation products with $\mathrm{PM}_{2.5}$ contribution of about $40-80 \%$. Aerosol of middle troposphere is characterized with more particles in the accumulation mode relative to lower tropospheric spectra, as results of precipitation scavenging and deposition of smaller and larger particles (Seinfeld and Pandis 1998). The shape and size distribution of desert aerosol is similar to that of remote continental aerosol but depends strongly on the wind velocity and only particles smaller than $10 \mu \mathrm{m}$ are transported over long distances (Seinfeld and Pandis 1998).

Adverse health effects from air pollution are influenced by particle size, chemical composition, and solubility (Carter et al. 1997; Samet et al. 2000). Industrial facilities, fossil fuel burning, waste incineration plants, and traffic are considered to be main sources of anthropogenic heavy metal emission (Zereini et al. 2005). Significant portion of elements in atmospheric aerosols originates from natural sources like desert dust, volcanic dust, re-suspension, biomass burning, etc. (Rodríguez et al. 2003; Bukowiecki et al. 2011; Handler et al. 2008; Paris et al. 2010).

Elements such as $\mathrm{As}, \mathrm{Cd}, \mathrm{Co}, \mathrm{Ni}, \mathrm{Pb}, \mathrm{Sb}, \mathrm{V}, \mathrm{Zn}$, and the platinum group of elements ( $\mathrm{Pt}, \mathrm{Pd}$, and $\mathrm{Rh}$ ) can be characterized as road-specific heavy metals derived from combustion and losses from fuels, engine, and transmission oils, abrasion from tires, brake linings, exhaust catalysts, road pavement, and corrosion of galvanized protection barriers (Zereini et al. 2005). Even low concentrations of some heavy metals in airborne particles such as $\mathrm{Pb}$, As, and Se may cause negative health effects (Utsunomiya et al. 2004).

Lately, a number of authors describe the morphology of collected aerosol samples by electron microscopy studies (Blanco et al. 2003; Wittmaack 2005; Nguyen et al. 2006; Sinha et al. 2008; Bern et al. 2009; Martin et al. 2010; Conny 2011; Sánchez de la Campa et al. 2013; Pietrodangelo et al. 2014). Morphology is an important microphysical trait that relates to particle aerodynamic behavior, possible health effects (Gelencsér et al. 2011), direct trace metal identification (Utsunomiya et al. 2004), formation mechanism, and source identification (Moffet et al. 2008; Ault et al. 2012).

In this work, we categorize mass distributions of urban aerosols provide information on morphology using highresolution images obtained by scanning electron microscopy and information about the elemental composition obtained by energy dispersive X-ray analysis and metal analysis of characteristic samples using ICP-MS. The main goal of this study is to investigate physical and chemical characteristics of continental urban aerosols and assess the main origin of particulate matter with emphasis on its morphology and chemical characterization. Special attention was paid to distribution of metal concentrations in samples from various origins.

\section{Materials and methods}

\section{Sampling}

Size-segregated aerosol samples were collected in urban area of Belgrade (44 $\left.49^{\prime} 10.08^{\prime \prime} \mathrm{N}-20^{\circ} 27^{\prime} 32.47^{\prime \prime} \mathrm{E}\right)$ using high-volume cascade impactor, model TE-236 (Tisch Environmental Inc., USA) in the following six size fractions: $\mathrm{PM}_{<0.49}, \mathrm{PM}_{0.49-0.95}, \mathrm{PM}_{0.95-1.5}, \mathrm{PM}_{1.5-3.0}$, $\mathrm{PM}_{3.0-7.2}, \mathrm{PM}_{>7.2}$ (Đorđević et al. 2012, 2014; MihajlidiZelić et al. 2015). 


\section{Gravimetric measurements}

Gravimetric measurements of the collected samples have been performed in a clean room (class 100) in a glove box system with nitrogen atmosphere (temperature $20 \pm 5^{\circ} \mathrm{C}$ and humidity $45 \pm 5 \%$ ) using KERN ABT 120-5DM balance (accuracy class I and precision of $0.01 \mathrm{mg}$ ). Before their use, filters from mixed cellulose ester were washed in $1 \% \mathrm{HNO}_{3}$ for $24 \mathrm{~h}$, dried in a clean room environment, and stored singularly. Samples and blanks were stored in freezer $\left(-20^{\circ} \mathrm{C}\right)$ till their processing.

\section{Chemical analysis}

For elemental analysis of sampled aerosols, acid microwave digestion with $\mathrm{HNO}_{3}\left(6 \mathrm{~cm}^{3}\right), \mathrm{H}_{2} \mathrm{O}_{2}\left(2 \mathrm{~cm}^{3}\right)$, and $\mathrm{HF}\left(3 \mathrm{~cm}^{3}\right)$ using Milestone ${ }^{\circledR}$ HPR-1000/10S high-pressure temperaturecontrolled microwave oven and subsequent ICP-QMS (inductively coupled plasma-quadrupole mass spectrometer, Agilent 7500I)) analyses were applied. The accuracy and precision of the method was controlled using the standard reference material (Urban Particulate Matter NIST ${ }^{\circledR}$ 1684a) (Stortini et al. 2009; Đorđević et al. 2014).

\section{Electron microscopic studies}

Electron microscopic imaging of aerosol samples was accomplished using SEM (Nova NanoSEM 230, FEI, Hillsboro, OR) (Schlagenhauf et al. 2012; Buha et al. 2014) in order to get information on the primary particle size, particle morphology, and aggregation status. EDX (energy dispersive X-ray) analysis was carried out to obtain information on the spatially resolved chemical composition, and the results were further compared to those obtained by ICP-QMS. Analysis was performed for all samples, but only results for four representative samples are presented here.

\section{Results and discussion}

\section{Aerosol mass distributions}

Average mass concentration of investigated aerosol showed dominance in the fine mode (with amount of about $65 \%$ ) and the mean concentration of coarse mode is around $35 \%$. The dominant components of fine mode are sulfates and ammonium ion (Đorđević et al. 2012) while $\mathrm{Al}, \mathrm{Ca}$, and $\mathrm{Fe}$ are dominating in the coarse mode (Đordević et al. 2014).

The results of mass concentration of collected samples comprised in six size ranges are presented in mass distributions. In our previous work, dominant air masses for each sample are identified (Mihajlidi-Zelić et al. 2015). Three characteristic types of mass distributions are observed: (1) with
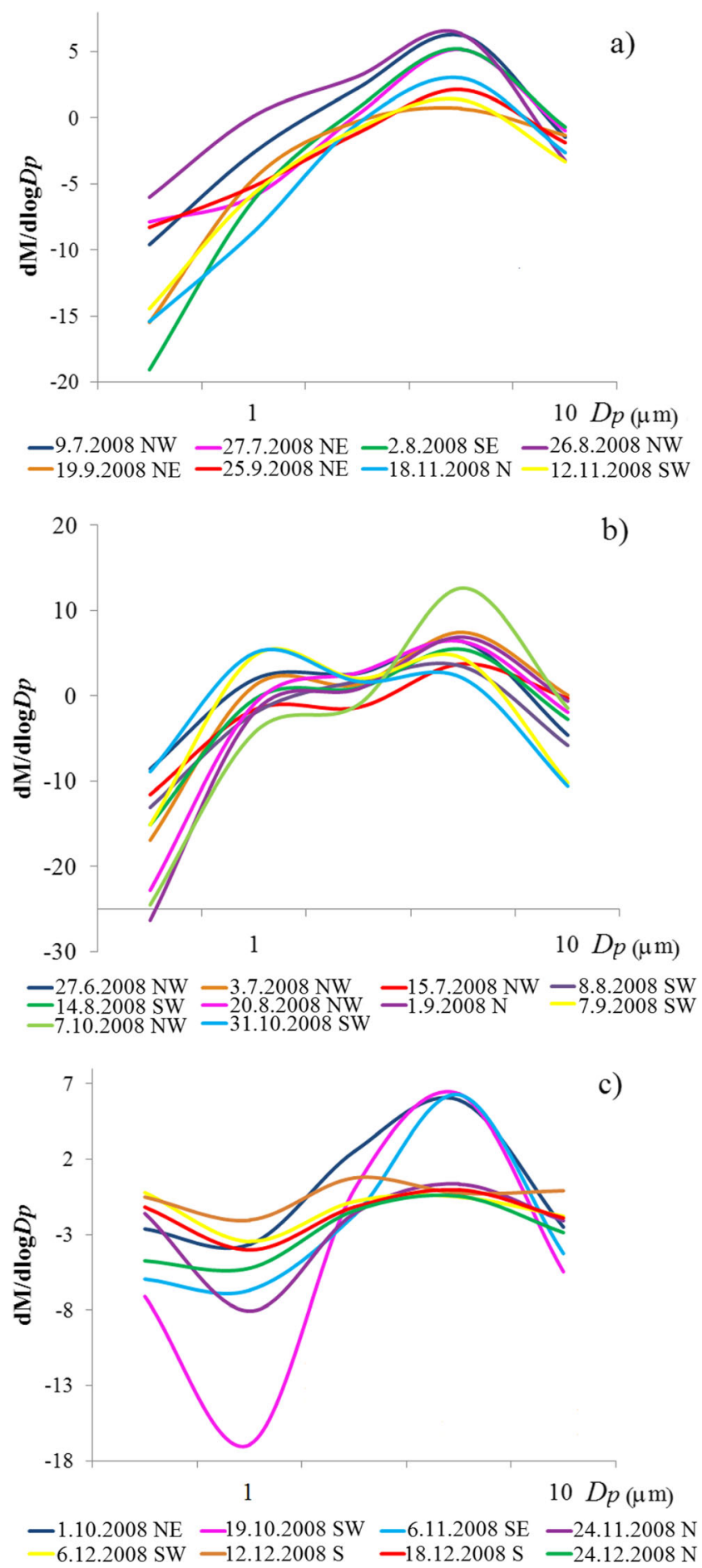

Fig. 1 Three types of characteristic mass distributions of investigated urban aerosol: a with dominant of coarse mode, $\mathbf{b}$ bimodal distributions, and $\mathbf{c}$ distributions with the minimum around $1 \mu \mathrm{m}$

distinctly dominant coarse mode (Fig. 1a) in the interval 3.0 $<D_{p} \leq 7.2 \mu \mathrm{m}$, (2) bimodal distribution (Fig. 1b) with first peak in the range $0.95<D_{p} \leq 1.5 \mu \mathrm{m}$ and other in the range $3.0<D_{p} \leq 7.2 \mu \mathrm{m}$, and (3) distribution (Fig. 1c) with the maximum in the coarse mode $3.0<D_{p} \leq 7.2 \mu \mathrm{m}$ and a pronounced minimum at $0.95<D_{p} \leq 1.5 \mu \mathrm{m}$. 

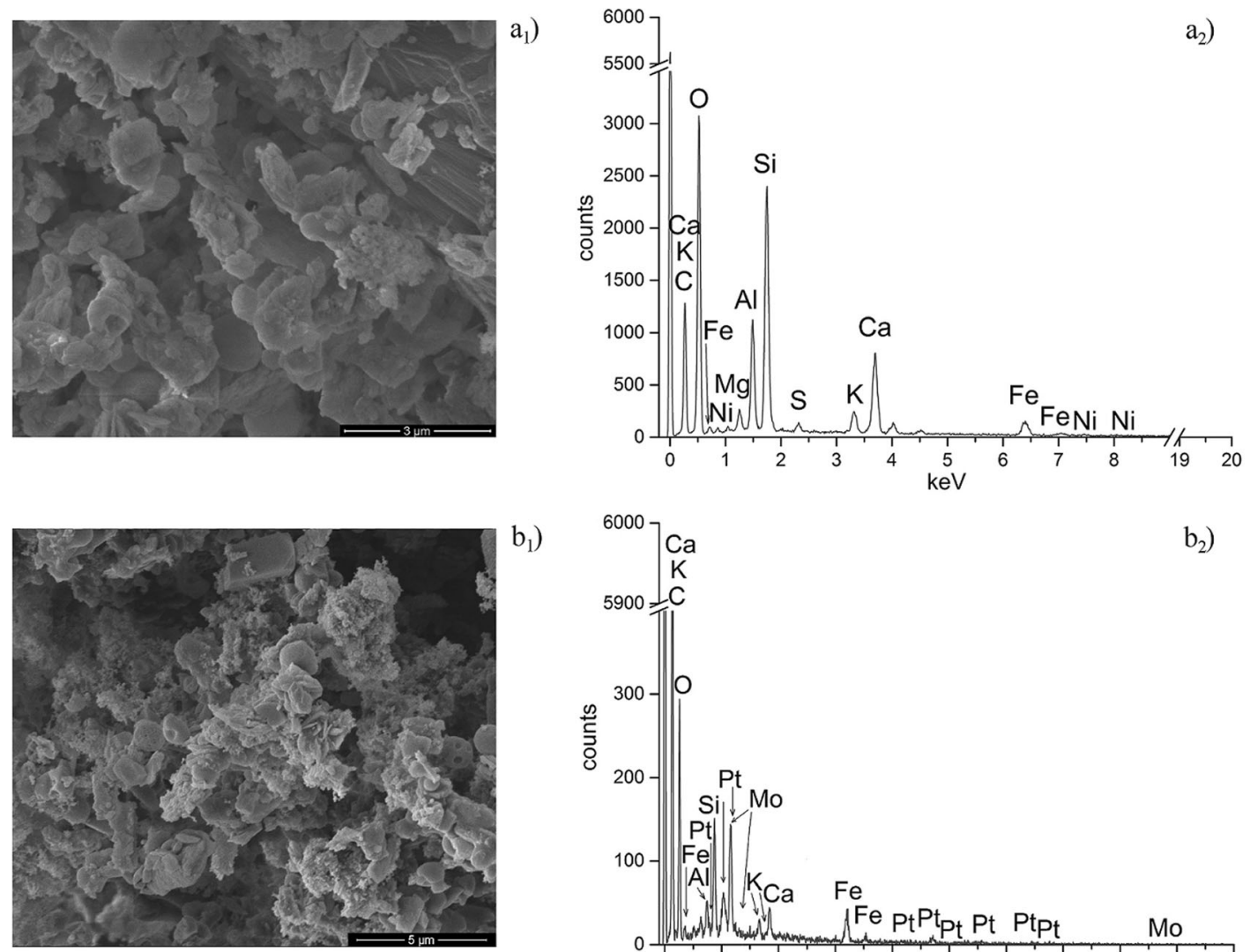

$\left.b_{1}\right)$
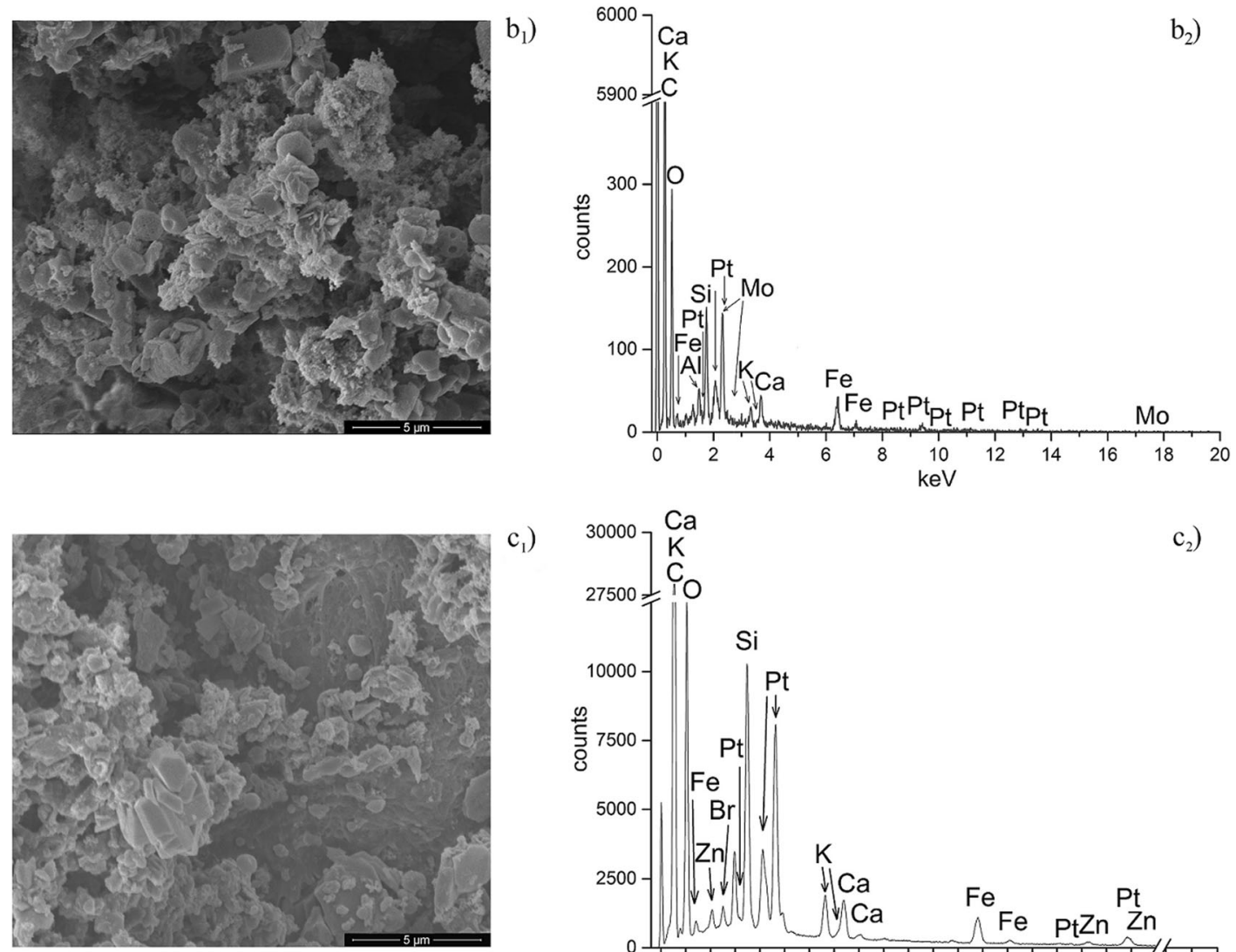

$\left.c_{1}\right)$
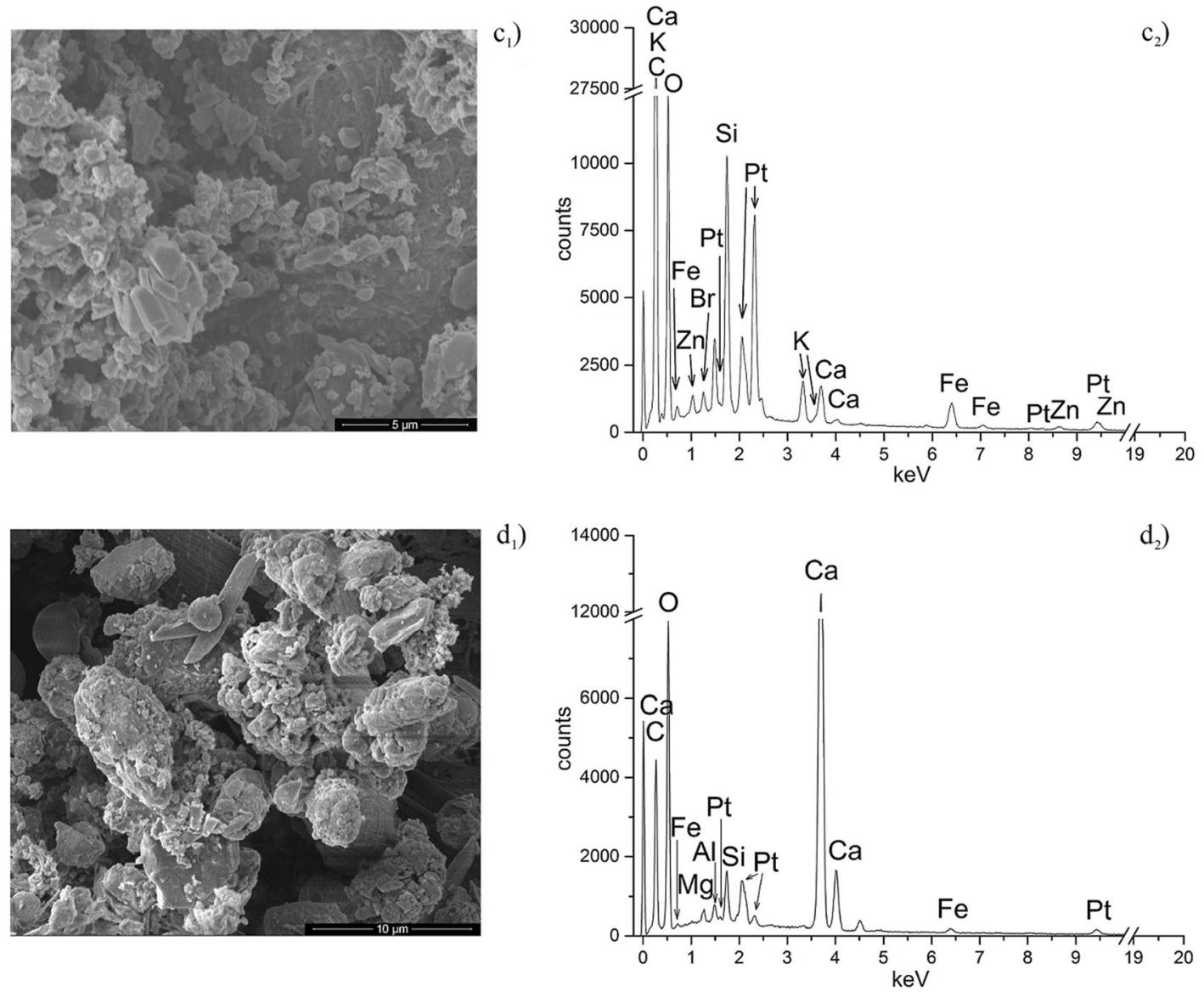
4 Fig. 2 SEM images $\left(a_{1}, b_{1}, c_{1}\right.$ and $\left.d_{1}\right)$, and EDX spectrums $\left(a_{2}, b_{2}, c_{2}\right.$, and $\mathrm{d}_{2}$ ) of samples collected in the following periods: 7-9 September 2008 (SW), 13-15 October 2008 (NW), 6-8 November 2008 (SE), and 18-20 November $2008(\mathrm{~N})$, respectively

The first type of mass distribution (Fig. 1a) presents the samples collected during air masses mainly arriving from continental northern, northeastern, and southeastern segments $(\mathrm{N}$, NE, SE), respectively, (Mihajlidi-Zelić et al. 2015) with the exception of the samples collected on 9-11 July 2008 and 2628 August 2008 (northwestern (NW) air masses) and on 1214 November 2008 (southwestern (SW) air masses). Although the distributions of these samples have mild features of the bimodal distribution, the first mode is not as clearly expressed as in Fig. 1b. The type of mass distribution of these samples may be associated with continental aerosols with a slight marine influence.

The second type of mass distribution (Fig. 1b) is characteristic for the samples collected during the prevalence of air masses from NW and SW segments with exception of the sample collected 1-3 September 2008 when N air masses prevailed. NW and SW air masses are arriving from the Atlantic and the Mediterranean, respectively, and this form of bimodal mass distribution can be linked to the marine aerosol combined with the continental aerosol. In our previous studies using the components of marine aerosols $\left(\mathrm{Na}^{+}, \mathrm{Cl}^{-}, \mathrm{Mg}^{2+}\right)$ and prevailing air masses, we could detect significant influence of marine aerosols in the urban area of the central Balkans (Đorđević et al. 2012, 2014; Mihajlidi-Zelić et al. 2015).

For the third type of mass distribution (Fig. 1c), there was no observed dominance of any air mass, although the trends are more or less similar with a minimum at $D_{p} \approx 1 \mu \mathrm{m}$ for each sample. Taking into account mass and volume distributions that are directly related via density of aerosols' material $(\rho)$ given in Eq. (1) (Seinfeld and Pandis 1998) measured mass distributions can be used to identify the origin of aerosols by comparing with volume distributions. It might be expected that the urban mass distribution is in relation to urban volume distribution that has a minimum at about $D_{p} \approx 1 \mu \mathrm{m}$.

\section{Electron microscopy and energy dispersive X-ray measurements}

Electron microscopy analyses (SEM) of the aerosol samples were performed in order to get information of the size, morphology, and aggregation status of particles. Energy dispersive X-ray (EDX) analysis was performed to obtain information on the spatially resolved chemical composition. Several samples representing different air masses were selected for SEM/EDX analyses and four representative samples are presented here (Fig. 2). For these samples, we have performed SEM imaging and EDX analyses. Agglomerates ranging from hundreds of nanometers to several micrometers in size were observed in the aerosol samples (Fig. $2 a_{1}, b_{1}, c_{1}$, and $d_{1}$ ). The SEM images showed that smaller particles were agglomerates of relatively small particles; the large particles had quite compact structures with large cores and some small primary particles attached to the surface. Figure $2 \mathrm{a}_{1}$ shows the morphology of the sample collected in the period 7-9 September 2008. During collection of this sample prevailing air masses were from SW segment-Mediterranean region (MihajlidiZelić et al. 2015). Different shapes and sizes of particles can be observed and EDX spectrum showed on Fig. $2 \mathrm{a}_{2}$. Mass distribution of this sample corresponds to marine aerosol (Fig. 1b).

Figure $2 b_{1}$ presents an image of aerosols collected in the period 13-15 October 2008, when NW air masses were prevailing (Mihajlidi-Zelić et al. 2015). The sample is porous with an abundance of small particles adsorbed on large ones. EDX spectrum of the collected aerosol is shown in Fig. $2 b_{2}$. Element/Si ratio and other ratios of elements in this sample are given in Table 1. Their mass distribution is characterized by pronounced peak in the range of coarse particles $3.0<D_{p} \leq 7.2 \mu \mathrm{m}$.

Figure $2 c_{1}$ shows the image of aerosols collected in the period 6-8 November 2008, during prevailing eastern continental air masses (SE). EDX spectrum of the collected aerosol is shown in Fig. $2 c_{2}$. Element/Si ratios are given in the Table 1. In this sample, the presence of $\mathrm{As}, \mathrm{Br}, \mathrm{Sn}$, and $\mathrm{Zn}$ is observed, which may be related to anthropogenic emission sources. Mass distribution of this sample (Fig. 1c) indicates anthropogenic urban activities from remote areas in SE segment, most likely coming from the outdated technologies in Serbia as well as in Southeastern Europe.

A source of As could be attributed to crude ore with a significant share of As and other microelements from mining complex Bor. In the SE directions are also two coal-fired power plants (Drmno and Kostolac) about $60 \mathrm{~km}$ far from Belgrade. Lignite with high As content is used in these power plants.

Figure $2 \mathrm{~d}_{1}$ shows the SEM image presenting the morphology of aerosols collected in the time interval 18-20 November 2008, when prevailing northern $(\mathrm{N})$ air masses were detected. EDX spectrum of collected aerosol is shown in Fig. $2 \mathrm{~d}_{2}$. Element/Si ratio and other ratios are given in the Table 1. Mass distribution of the sample also corresponds to the continental aerosols (Fig. 1a).

In our previous work, it was shown that the dominant air masses were from the west segment-SW (34.4\%) and NW $(28.1 \%)$, whereas the presence of air masses from the southeastern segment (SE) was less than $10 \%$ (Mihajlidi-Zelić et al. 2015).

EDX spectra (Fig. $2 \mathrm{a}_{2}, \mathrm{~b}_{2}, \mathrm{c}_{2}$, and $\mathrm{d}_{2}$ ) of the collected aerosols show that particles mainly contain the following elements: $\mathrm{Al}, \mathrm{Ca}, \mathrm{K}, \mathrm{Fe}, \mathrm{Mg}, \mathrm{Ni}, \mathrm{K}, \mathrm{Si}$, and $\mathrm{S}$ but in $\mathrm{SE}$ air masses additionally anthropogenic elements like $\mathrm{As}, \mathrm{Br}, \mathrm{Sn}$, and $\mathrm{Zn}$ have been found (Fig. 2 $c_{2}$ ). 
Table 1 Element/Si and other ratios of elements in samples collected during various air masses

\begin{tabular}{cccccccc}
\hline 7-9 September $2008(\mathrm{SW})$ \\
$\mathrm{Al} / \mathrm{Si}$ & 0.50 & $\mathrm{Ca} / \mathrm{Si}$ & 0.24 & $\mathrm{~K} / \mathrm{Si}$ & 0.13 & $\mathrm{Fe} / \mathrm{Si}$ & 0.26 \\
$\mathrm{Mg} / \mathrm{Si}$ & 0.12 & $\mathrm{Ni} / \mathrm{Si}$ & 0.15 & $\mathrm{~S} / \mathrm{Si}$ & 0.06 & $\mathrm{P} / \mathrm{Si}$ & 1.08 \\
$\mathrm{Ca} / \mathrm{Al}$ & 0.40 & $\mathrm{Si} / \mathrm{Al}$ & 2.10 & $\mathrm{Fe} / \mathrm{Ca}$ & 0.40 & $\mathrm{~K} / \mathrm{Ca}$ & 0.50 \\
$\mathrm{Mg} / \mathrm{Na}$ & 2.00 & & & & & & \\
$13-15 \mathrm{October} 2008(\mathrm{NW})$ & & & & & \\
$\mathrm{Al} / \mathrm{Si}$ & 0.27 & $\mathrm{Ca} / \mathrm{Si}$ & 0.48 & $\mathrm{~K} / \mathrm{Si}$ & 0.26 & $\mathrm{Fe} / \mathrm{Si}$ & 1.36 \\
$\mathrm{Mo} / \mathrm{Si}$ & 2.47 & $\mathrm{Ca} / \mathrm{Al}$ & 1.81 & $\mathrm{Si} / \mathrm{Al}$ & 3.77 & $\mathrm{Fe} / \mathrm{Ca}$ & 2.81 \\
$\mathrm{~K} / \mathrm{Ca}$ & 0.54 & $\mathrm{Mo} / \mathrm{Fe}$ & 1.82 & & & & \\
$6-8 \mathrm{November} 2008(\mathrm{SE})$ & & & & & \\
$\mathrm{Al} / \mathrm{Si}$ & 0.41 & $\mathrm{Ca} / \mathrm{Si}$ & 12.16 & $\mathrm{~K} / \mathrm{Si}$ & 0.08 & $\mathrm{Fe} / \mathrm{Si}$ & 0.55 \\
$\mathrm{As} / \mathrm{Fe}$ & 0.52 & $\mathrm{As} / \mathrm{Si}$ & 0.05 & $\mathrm{Br} / \mathrm{Si}$ & 1.09 & $\mathrm{Si} / \mathrm{Al}$ & 2.37 \\
$\mathrm{Zn} / \mathrm{Si}$ & 0.02 & $\mathrm{Zn} / \mathrm{Fe}$ & 0.27 & $\mathrm{Ca} / \mathrm{Al}$ & 1.04 & $\mathrm{Sn} / \mathrm{Zn}$ & 2.95 \\
$\mathrm{Fe} / \mathrm{Ca}$ & 0.01 & $\mathrm{~K} / \mathrm{Ca}$ & 0.93 & $\mathrm{Mg} / \mathrm{Si}$ & 0.07 & & \\
$18-20 \mathrm{November} 2008(\mathrm{~N})$ & & & & & \\
$\mathrm{Al} / \mathrm{Si}$ & 0.28 & $\mathrm{Ca} / \mathrm{Si}$ & 0.95 & $\mathrm{~K} / \mathrm{Si}$ & 0.23 & $\mathrm{Fe} / \mathrm{Si}$ & 0.54 \\
$\mathrm{As} / \mathrm{Fe}$ & 0.13 & $\mathrm{As} / \mathrm{Si}$ & 0.02 & $\mathrm{Ca} / \mathrm{Al}$ & 0.83 & $\mathrm{Fe} / \mathrm{V}$ & 5.44 \\
$\mathrm{~K} / \mathrm{Ca}$ & 1.78 & $\mathrm{Mg} / \mathrm{Si}$ & 0.08 & & & & \\
\hline
\end{tabular}

Comparison of the calculated ratios of elements and $\mathrm{Si}$ with ratios obtained in 2002 in Southern Italy in Lecce lead to the conclusion that the $\mathrm{Al} / \mathrm{Si}$ ratio is approximately equal to the ratio of the desert dust that is spread from parts of North Africa (Blanco et al. 2003). Ratios $\mathrm{Ca} / \mathrm{Si}$ and $\mathrm{Fe} / \mathrm{Si}$ are twice higher; $\mathrm{K} / \mathrm{Si}$ is at the level of that found in Southern Italy, whereas the ratios $\mathrm{Mg} / \mathrm{Si}$ and $\mathrm{S} / \mathrm{Si}$ are about $20 \%$ lower. Higher ratios of (crustal element)/Si point to stronger influence of resuspension in distant continental areas in relation to Lecce where the more significant impact of marine aerosol exists.

$\mathrm{Al} / \mathrm{Si}$ ratios in samples collected during air masses from $\mathrm{SW}(\mathrm{Al} / \mathrm{Si}=0.50)$ and $\mathrm{SE}(\mathrm{Al} / \mathrm{Si}=0.41)$ directions (Tables 1 and 3) correspond to the values found in transported desert dust demonstrating the impact of Saharan dust in the continental parts of Balkan Peninsula but also the impact of dust coming from Middle East deserts. Likewise, from SW and SE directions ratios $\mathrm{Ca} / \mathrm{Si}$ and $\mathrm{Ca} / \mathrm{Al}$ are significantly higher from those found in southern Italy (Blanco et al. 2003). The increase of $\mathrm{Ca}$ and therefore the high ratios of $\mathrm{Ca} / \mathrm{Si}$ and $\mathrm{Ca} / \mathrm{Al}$ may be due not only to the existence of limestone rocks in the western Balkan but also in a high proportion of calcite in dust and aerosols form North Africa. Dust and aerosols emanating from North Africa (Morocco) are rich in calcite (Moreno et al. 2006). Furthermore, calcite, dolomite, and feldspar are the dominant constituents of airborne dust from areas of Sahara, while quartz dominates in all aerosols originating from North Africa without indicating specific area of origin (Caquineau et al. 1998). Lower ratio $\mathrm{Fe} / \mathrm{Ca}$ than that found in Southern Italy also is most likely due to the higher content of $\mathrm{Ca}$ in atmospheric aerosol in the continental part of Balkan due to higher local crustal origin of $\mathrm{Ca}$. The ratio of $\mathrm{K} / \mathrm{Ca}$ from $\mathrm{SW}$ direction is considerably lower.

\section{Elemental analysis}

Average values of elements' distribution through $D_{p}$ intervals are shown in the Table 2. The dominant share of the nucleation mode is found for As, $\mathrm{K}, \mathrm{Ni}, \mathrm{V}$, and $\mathrm{U}$ pointing to anthropogenic emission sources, while for $\mathrm{Al}, \mathrm{Li}, \mathrm{Mg}, \mathrm{Ca}, \mathrm{Co}, \mathrm{Cr}, \mathrm{Fe}$, and $\mathrm{Mn}$ coarse mode dominates, pointing the crustal origin as dominant. These results are in agreement with our previous work where we pointed to the same origin of these elements (Đorđević et al. 2014).

According to the share of elements in the individual samples through fractions (Fig. 3), two extremely characteristic samples were singled out: (1) a sample collected in the period 7-9 September 2008 with prevailing Mediterranean air masses (SW), for which shares of all the above elements have
Table 2 Average percentage (\%) of element in PM fractions

\begin{tabular}{lllllll}
\hline & $\mathrm{PM}_{<0.49}$ & $\mathrm{PM}_{0.49-0.95}$ & $\mathrm{PM}_{0.95-1.5}$ & $\mathrm{PM}_{1.5-3.0}$ & $\mathrm{PM}_{3.0-7.2}$ & $\mathrm{PM}_{7.2-10}$ \\
\hline $\mathrm{Li}$ & $14.48 \pm 8.13$ & $4.11 \pm 4.36$ & $14.85 \pm 4.63$ & $19.88 \pm 5.66$ & $34.26 \pm 13.14$ & $12.42 \pm 3.94$ \\
$\mathrm{Mg}$ & $16.81 \pm 7.15$ & $10.38 \pm 5.74$ & $13.20 \pm 3.90$ & $16.23 \pm 5.29$ & $27.96 \pm 11.97$ & $12.49 \pm 4.53$ \\
$\mathrm{Al}$ & $15.96 \pm 6.74$ & $12.48 \pm 6.34$ & $14.21 \pm 4.06$ & $16.63 \pm 4.28$ & $29.07 \pm 10.89$ & $11.66 \pm 4.16$ \\
$\mathrm{~K}$ & $58.70 \pm 17.00$ & $13.60 \pm 4.62$ & $6.55 \pm 5.79$ & $6.01 \pm 5.08$ & $11.43 \pm 8.75$ & $3.72 \pm 3.09$ \\
$\mathrm{Ca}$ & $12.60 \pm 9.70$ & $7.93 \pm 3.81$ & $13.19 \pm 3.33$ & $18.31 \pm 3.85$ & $32.38 \pm 9.73$ & $15.59 \pm 3.62$ \\
$\mathrm{~V}$ & $57.30 \pm 13.69$ & $9.05 \pm 3.13$ & $9.07 \pm 6.71$ & $8.27 \pm 3.28$ & $11.54 \pm 4.93$ & $4.76 \pm 2.23$ \\
$\mathrm{Cr}$ & $21.93 \pm 10.30$ & $12.04 \pm 5.46$ & $11.53 \pm 4.42$ & $18.32 \pm 4.64$ & $27.33 \pm 8.24$ & $8.84 \pm 3.24$ \\
$\mathrm{Mn}$ & $22.78 \pm 4.77$ & $12.59 \pm 2.90$ & $13.66 \pm 3.88$ & $15.39 \pm 3.12$ & $23.60 \pm 7.52$ & $11.98 \pm 5.31$ \\
$\mathrm{Fe}$ & $13.65 \pm 4.12$ & $9.95 \pm 4.12$ & $15.93 \pm 4.00$ & $19.92 \pm 3.67$ & $29.61 \pm 9.04$ & $10.94 \pm 2.66$ \\
$\mathrm{Co}$ & $6.02 \pm 5.83$ & $2.20 \pm 3.77$ & $20.60 \pm 4.87$ & $23.09 \pm 3.37$ & $29.59 \pm 6.54$ & $18.50 \pm 4.48$ \\
$\mathrm{Ni}$ & $49.59 \pm 11.93$ & $10.75 \pm 3.10$ & $9.98 \pm 6.18$ & $9.87 \pm 3.12$ & $14.87 \pm 5.26$ & $4.94 \pm 2.36$ \\
$\mathrm{Ga}$ & $20.08 \pm 7.68$ & $12.42 \pm 4.75$ & $13.82 \pm 4.38$ & $17.43 \pm 6.09$ & $26.28 \pm 7.94$ & $9.98 \pm 3.41$ \\
$\mathrm{As}$ & $58.45 \pm 14.76$ & $11.71 \pm 4.73$ & $9.55 \pm 6.39$ & $7.44 \pm 4.69$ & $9.32 \pm 5.98$ & $3.53 \pm 2.87$ \\
$\mathrm{U}$ & $36.32 \pm 2.86$ & $37.40 \pm 3.10$ & $6.34 \pm 1.67$ & $7.12 \pm 2.37$ & $7.85 \pm 2.87$ & $4.97 \pm 1.38$ \\
\hline
\end{tabular}



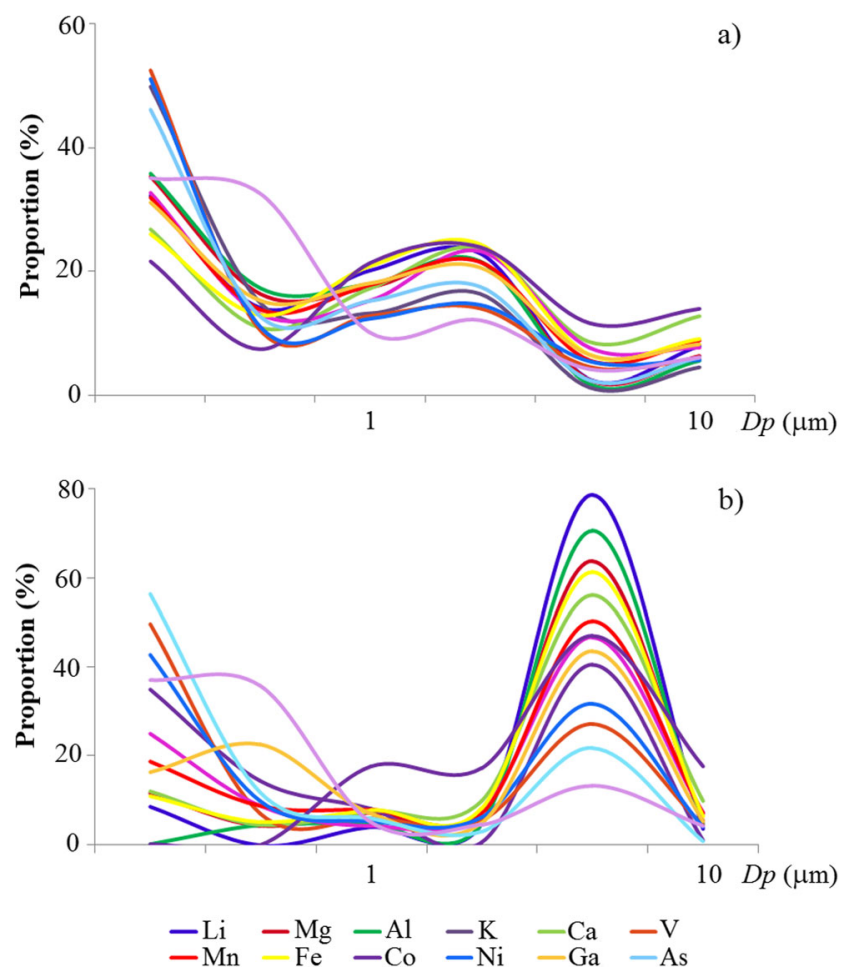

Fig. 3 Share of elements through PM fractions in characteristics samples: a sample collected during Mediterranean air masses 7-9 September 2008 (SW) and b sample collected during continental air masses 19-21 September 2008 (NE)

a minimum in the range of coarse mode and (2) a sample collected in the period 19-21 September 2008 with prevailing $\mathrm{NE}$ air masses, characterized by maximum shares of all the above elements in the range of coarse mode. This result could be included as additional approach for identifying the origin of marine and continental aerosols.

In Mediterranean air masses (SW) (Fig. 3a), the share of crustal elements is minimal in the coarse mode of aerosols collected in the measured campaign of central Balkans indicating a strong influence of marine aerosols in this region. The influence of re-suspension is dominant for continental air masses (NE) (Fig. 3b).

The share of crustal elements in the nuclei mode for some samples is extremely high. It should be noted that in the sample collected from 7-9 September 2008, in the nucleation mode, the absolute highest contents of $\mathrm{Al}, \mathrm{Ga}, \mathrm{Li}, \mathrm{Mg}, \mathrm{Co}$, and $\mathrm{Cr}$ were recorded in the whole measured campaign. The maximum value of $\mathrm{Al}$ measured in this sample (336.1 $\mathrm{ng} \mathrm{m}^{-3}$ ) was about eight times higher the average content of $\mathrm{Al}$ in the $\mathrm{PM}_{<0.49}$ fraction, which is $42.7 \mathrm{ng} \mathrm{m}^{-3}$ (Đorđević et al. 2014) In the marine aerosols, such extremely high value of $\mathrm{Al}$ content is not expected, especially not in the nucleation mode. It is well known that crustal $\mathrm{Al}$ is in the coarse mode. The coincidence is that these extremely high values of $\mathrm{Al}$ in nucleation mode measured during the Mediterranean air masses (SW) are accompanied by low amount of $\mathrm{Al}$ in coarse mode (Table 3). The mean value of $\mathrm{Al}$ for the whole measuring campaign in the fraction of coarse mode $\mathrm{PM}_{3.0-7.2}$ was $65.4 \pm 45.6 \mathrm{ng} \mathrm{m}^{-3}$, but in this sample, the measured value in coarse mode is $17.16 \mathrm{ng} \mathrm{m}^{-3}$ (Table 3). Aluminum as crustal component cannot be found in the nucleation mode. Our result of $\mathrm{Al}$ in nucleation mode indicates an anthropogenic origin, most probably connected with global geo-engineering regarding the ongoing global climate modification programs by spraying tens

Table 3 Size-segregated concentrations $\left(\mathrm{ng} \mathrm{m}^{-3}\right)$ of elements in characteristic samples collected during Mediterranean air masses 7-9 September 2008 (SW) and continental air masses 19-21 September 2008 (NE)

7-9 September 2008 (SW)

\begin{tabular}{|c|c|c|c|c|c|c|c|c|c|c|c|c|}
\hline & & \\
\hline & $\mathrm{PM}_{<0.49}$ & $\mathrm{PM}_{0.49-0.95}$ & $\mathrm{PM}_{0.95-1.5}$ & $\mathrm{PM}_{1.5-3.0}$ & $\mathrm{PM}_{3.0-7.2}$ & $\mathrm{PM}_{7.2-10}$ & $\mathrm{PM}_{<0.49}$ & $\mathrm{PM}_{0.49-0.95}$ & $\mathrm{PM}_{0.95-1.5}$ & $\mathrm{PM}_{1.5-3.0}$ & $\mathrm{PM}_{3.0-7.2}$ & $\mathrm{PM}_{7.2-10}$ \\
\hline $\mathrm{Li}$ & 0.22 & 0.10 & 0.14 & 0.16 & 0.02 & 0.05 & 0.02 & 0.00 & 0.01 & 0.01 & 0.14 & 0.01 \\
\hline $\mathrm{Mg}$ & 75.42 & 35.00 & 37.34 & 46.17 & 5.44 & 13.66 & 6.81 & 2.54 & 4.23 & 4.46 & 37.23 & 3.18 \\
\hline $\mathrm{Al}$ & 336.12 & 162.34 & 168.80 & 203.05 & 17.16 & 52.25 & 23.84 & 9.60 & 10.19 & 10.41 & 152.58 & 9.62 \\
\hline $\mathrm{K}$ & 159.82 & 47.80 & 42.37 & 52.54 & 4.03 & 14.35 & 40.90 & 16.95 & 9.70 & 0.78 & 47.55 & 1.34 \\
\hline $\mathrm{Ca}$ & 181.48 & 74.06 & 117.00 & 160.75 & 58.48 & 86.80 & 36.20 & 13.69 & 22.89 & 29.93 & 168.46 & 29.59 \\
\hline V & 1.48 & 0.29 & 0.36 & 0.40 & 0.13 & 0.16 & 0.66 & 0.09 & 0.08 & 0.08 & 0.36 & 0.06 \\
\hline $\mathrm{Cr}$ & 0.61 & 0.25 & 0.29 & 0.43 & 0.14 & 0.14 & 0.22 & 0.08 & 0.04 & 0.07 & 0.41 & 0.07 \\
\hline $\mathrm{Mn}$ & 4.21 & 1.83 & 2.36 & 2.85 & 0.75 & 1.18 & 1.03 & 0.48 & 0.43 & 0.40 & 2.76 & 0.39 \\
\hline $\mathrm{Fe}$ & 201.84 & 100.71 & 161.90 & 189.29 & 50.97 & 70.71 & 31.14 & 14.81 & 22.19 & 23.31 & 173.90 & 18.59 \\
\hline Co & 0.08 & 0.03 & 0.07 & 0.08 & 0.04 & 0.05 & 0.00 & 0.00 & 0.03 & 0.03 & 0.08 & 0.03 \\
\hline $\mathrm{Ni}$ & 0.82 & 0.18 & 0.20 & 0.23 & 0.09 & 0.09 & 0.32 & 0.07 & 0.04 & 0.05 & 0.23 & 0.03 \\
\hline $\mathrm{Ga}$ & 0.18 & 0.09 & 0.11 & 0.12 & 0.04 & 0.05 & 0.04 & 0.06 & 0.02 & 0.01 & 0.11 & 0.01 \\
\hline As & 0.77 & 0.21 & 0.25 & 0.29 & 0.04 & 0.10 & 0.72 & 0.15 & 0.08 & 0.04 & 0.28 & 0.01 \\
\hline $\mathrm{U}$ & 0.03 & 0.03 & 0.01 & 0.01 & 0.00 & 0.01 & 0.03 & 0.03 & 0.00 & 0.00 & 0.01 & 0.00 \\
\hline
\end{tabular}

19-21 September 2008 (NE) 
of millions of tons of nanoparticulates containing metals among is aluminum.

\section{Conclusion}

Analyzing the results of the calculated mass distribution, it is observed that there are three characteristic types of mass distributions: (1) with pronounced domination of coarse mode that can be associated with continental aerosols followed by slight influence of marine aerosols, (2) bimodal distribution which may be related to marine aerosol combined with continental, and (3) distribution most similar to those described in the urban aerosol. Generally, the following elements are dominating: $\mathrm{Al}, \mathrm{Ca}, \mathrm{K}, \mathrm{Fe}, \mathrm{Mg}, \mathrm{Ni}, \mathrm{K}, \mathrm{Si}$, and $\mathrm{S}$, but samples collected during the air masses coming from southeast segment contain $\mathrm{As}, \mathrm{Br}, \mathrm{Sn}$, and $\mathrm{Zn}$ whose origin is from combustion and other anthropogenic activities. Ratios $\mathrm{Al} / \mathrm{Si}$ in the aerosol collected when southwestern (SW) and southeastern (SE) air masses prevailed correspond to desert dust arriving from North Africa and Middle East. Al/Si ratios in the aerosols arriving with others air masses are significantly lower.

According to the share of elements through fractions, two characteristic samples were singled out: (1) a sample with minimum share of the crustal elements in the coarse mode collected when Mediterranean air masses prevailed and (2) a sample with maximum share of the crustal elements in the coarse mode affected by continental air masses. This result could be included as additional approach for identification of the origin of marine and continental aerosol. High values of aluminum in the nucleation mode could be connected to anthropogenic origin most probably with global geo-engineering regarding the ongoing global climate modification programs.

Acknowledgments This work was supported by the INTERREG/ CARDS-PHARE Adriatic New Neighborhood Programme-Grant No. 06SER02/01/04. The authors are grateful to the Delegation of the European Union to Serbia. The authors are also grateful to the Ministry of Education, Science, and Technological Development which further supported financially this research within the projects 172001 and 43007 and to the Swiss Federal Office for the Environment (FOEN).

\section{References}

Ault AP, Peters TM, Sawvel EJ, Casuccio GS, Willis RD, Norris GA, Grassian VH (2012) Single-particle SEM-EDX analysis of ironcontaining coarse particulate matter in an urban environment: sources and distribution of iron within Cleveland, Ohio. Environ Sci Technol 46:4331-4339

Bern AM, Lowers HA, Meeker GP, Rosati JA (2009) Method development for analysis of urban dust using scanning electron microscopy with energy dispersive $\mathrm{x}$-ray spectrometry to detect the possible presence of world trade center dust constituents. Environ Sci Technol 43:1449-1454
Blanco A, De Tomasi F, Filippo E, Manno D, Perrone MR, Serra A, Tafuro AM, Tepore A (2003) Characterization of African dust over Southern Italy. Atmos Chem Phys 3:2147-2159

Buha J, Muller N, Nowack B, Ulrich A, Losert S, Wang J (2014) Physical and chemical characterisation of fly ash from swiss waste incineration plants and determination of the ash fraction in the nanometer range. Environ Sci Technol 48:4765-4773

Bukowiecki N, Zieger P, Weingartner E, Jurányi Z, Gysel M, Neininger B, Schneider B, Hueglin C, Ulrich A, Wichser A, Henne S, Brunner D, Kaegi R, Schwikowski M, Tobler L, Wienhold FG, Engel I, Buchmann B, Peter T, Baltensperger U (2011) Ground-based and airborne in-situ measurements of the Eyjafjallajökull volcanic aerosol plume in Switzerland in spring 2010. Atmos Chem Phys 11: 10011-10030

Caquineau S, Gaudichet A, Gomes L, Magonthier M-C, Chatenet B (1998) Saharan dust: clay ratio as a relative tracer to assess the origin of soil-derived aerosols. Geophys Res Lett 25:983-986

Carter JD, Ghio AJ, Samet JM, Devlin RB (1997) Cytokine production by human airway epithelial cells after exposure to an air pollution particle is metal dependent. Toxicol Appl Pharmacol 146:180-188

Conny JM (2011) Scanning electron microanalysis and analytical challenges of mapping elements in urban atmospheric particles. Environ Sci Technol 45:7380-7386

Đorđević D, Mihajlidi-Zelić A, Relić D, Lj I, Huremović J, Stortini AM, Gambaro A (2012) Size-segregated mass concentration and water soluble inorganic ions in an urban aerosol of the Central Balkans (Belgrade). Atmos Environ 46:309-317

Đorđević D, Stortini AM, Relić D, Mihajlidi-Zelić A, Huremović J, Barbante C, Gambaro A (2014) Size-segregated of trace elements contents in urban aerosols with related to anthropogenic emission sources and the re-suspension. Environ Sci Pollut Res 21:1094910959

Gelencsér A, Kováts N, Turóczi B, Rostási A, Hoffer A, Imre K, NuirőKósa I, Csákberényi-Malasics D, Tóth A, Czitrovszky A, Nagy A, Nagy S, Acs A, Kovács A, Ferincz A, Hartyáni Z, Posfai M (2011) The red mud accident in Ajka (Hungary): characterization and potential health effects of fugitive dust. Environ Sci Technol 45:16081615

Handler M, Puls C, Zbiral J, Marr I, Puxbaum H, Limbeck A (2008) Size composition of particulate emission from motor vehicles in the Kaisermühlen-Tunnel, Vienna. Atmos Environ 42:2173-2186

Heintzenberg J, Birmili W, Otto R, Andreae MO, Mayer J-C, Chi X, Panov A (2011) Aerosol particle number size distributions and particulate light absorption at the ZOTTO tall tower (Siberia), 20062009. Atmos Chem Phys 11:8703-8719

Martin ST, Andreae MO, Althausen D, Artaxo P, Baars H, Borrmann S, Chen Q, Farmer DK, Guenther A, Guenthe SS, Jiminez JL, Karl T, Longo K, Manzi A, Müller T, Pauliquevis T, Petters MD, Prenni AJ, Pöschi U, Rizzo LV, Schneider J, Smith JN, Swietlicki E, Tota J, Wang J, Wiedensohler A (2010) An overview of Amazonian aerosol characterization experiment 2008 (AMAZE-8). Atmos Chem Phys 10:11415-11438

Mihajlidi-Zelić A, Đorđević D, Relić D, Tošić I, Ignjatović LJ, Stortini MA, Gambaro A (2015) Water-soluble inorganic ions in urban aerosols of the continental part of Balkans (Belgrade) during the summer-autumn (2008). Open Chem 13:245-256

Moffet CR, Desyaterik Y, Hopkins RJ, Tivanski AV, Gilles MK, Wang Y, Shutthanandan V, Molina LT, Abraham RG, Johnson KS, Mugica V, Molina MJ, Laskin A, Prather KA (2008) Characterization of aerosol containing $\mathrm{Zn}, \mathrm{Pb}$, and $\mathrm{Cl}$ from industrial region of Mexico City. Environ Sci Technol 42:7091-7097

Mogo S, Cachorro VE, de Frutos AM (2005) Morphological, chemical and optical absorbing characterization of aerosols in the urban atmosphere of Valladolid. Atmos Chem Phys 5:2739-2748

Moreno T, Querol X, Alastuey A, Garciado Santos S, Fernandez Patier R, Artinano B, Gibbons W (2006) PM source apportionment and trace 
metallic aerosol affinities during atmospheric pollution episodes: a case study from Puertollano, Spain. J Environ Monit 8:1060-1068

Nguyen TH, Sabbah I, Ball WP (2006) Immobilization of soot particles in a silica matrix: a sorbent-carrier system for studying organic chemical sorption. Environ Sci Technol 39:6527-6534

Paris R, Desboeufs KV, Formenti P, Nava S, Chou C (2010) Chemical characterisation of iron in dust and biomass burning aerosols during AMMA-SOP0/DABEX: implication for iron solubility. Atmos Chem Phys 10:4273-4282

Pietrodangelo A, Pareti S, Perrino C (2014) Improved identification of transition metals in airborne aerosols by SEM-EDX combined backscattered and secondary electron microanalysis. Environ Sci Pollut Res 21:4023-4031

Rodríguez S, Querol X, Alastuey A, Viana M-M, Mantilla E (2003) Events affecting levels and seasonal evolution of airborne particulate matter concentrations in the Western Mediterranean. Environ Sci Technol 37:216-222

Samet JM, Dominici F, Curriero FC, Coursac I, Zeger SL (2000) Fine particulate air pollution and mortality in 20 US cities, 1987-1994. N Eng J Med 343:1742-1749

Sánchez de la Campa A, Garciá-Salamanca A, Solano J, de la Rosa J, Ramos JL (2013) Chemical and microbiological characterization of atmospheric particulate matter during an intense African dust event in Southern Spain. Environ Sci Technol 47:3630-3638
Schlagenhauf L, Chu BTT, Buha J, Nüesch F, Wang J (2012) Release of carbon nanotubes from an epoxy-based nanocomposite during an abrasion process. Environ Sci Technol 46:7366-7372

Seinfeld JH, Pandis SN (1998) Atmospheric chemistry and physics: from air pollution to climate change. Wiley, New York

Sinha BW, Hoppe P, Huth J, Foley S, Andreae MO (2008) Sulfur isotope analysis of individual aerosol particles in the aerosol at a central European site (Mainz, Germany). Atmos Chem Phys 8:7217-7238

Stortini AM, Freda A, Cesari D, Cairns WRL, Contini D, Barbante C, Prodi F, Cescon P, Gambaro A (2009) An evaluation of the PM2.5 trace elemental composition in the Venice lagoon area and an analysis of the possible sources. Atmos Environ 43:6296-6304

Utsunomiya S, Jensen KA, Keeler GJ, Ewing RC (2004) Direct identification of trace metals in fine and ultrafine particles in the Detroit urban atmosphere. Environ Sci Technol 38:2289-2297

Wittmaack K (2005) Combustion characteristics of water-insoluble elemental and organic carbon in size selected ambient aerosol particles. Atmos Chem Phys 5:1905-1913

Zereini F, Alt F, Messer Chmidt J, Wiseman C, Feldmann I, von Bohlen A, Müller J, Liebl K, Püttmann W (2005) Concentration and distribution of heavy metals in urban airborne particulate matter in Frankfurt am Main, Germany. Environ Sci Technol 39:2983-2989 